\title{
EDXRF STUDY OF TUPI-GUARANI ARCHAEOLOGICAL CERAMICS
}

\author{
Fernando R. Espinoza Quiñones* \\ Carlos R. Appoloni** \\ Adenilson O. dos Santos** \\ Luzeli M. da Silva** \\ Paulo F. Barbieri** \\ Pedro H. Aragão** \\ Virgílio F. do Nascimento Filho*** \\ Melayne M. Coimbra**
}

\begin{abstract}
ESPINOZAQUIÑONES, F.R.; APPOLONI, C.R.; DOS SANTOS, A.O.; DA SILVA, L.M.; BARBIERI, P.F.;ARAGÃO, P.H.; DO NASCIMENTO FILHO, V.F.; COIMBRA, M.M. EDXRF

study of Tupi-Guarani archaeological ceramics. Rev. do Museu de Arqueologia e Etnologia, São Paulo, 13: 199-210, 2003.
\end{abstract}

RESUMO: Um conjunto de fragmentos cerâmicos indígenas brasileiros pertencentes à Tradição Tupi-Guarani foi estudado por uma técnica arqueométrica não destrutiva. Os fragmentos cerâmicos foram descobertos acidentalmente na fazenda Santa Dalmácia, situada próximo da cidade de Cambé, no norte do estado do Paraná. Cada um desses fragmentos veio de diferentes recipientes cerâmicos e suas características físicas são muito similares. As medidas EDXRF foram realizadas empregando tanto um tubo de raios $\mathrm{X}$ como três fontes de radioisótopos $\left({ }^{55} \mathrm{Fe},{ }^{109} \mathrm{Cd} \mathrm{e}{ }^{238} \mathrm{Pu}\right)$. Os dados de composição da pasta cerâmica e dos pigmentos são investigados. Para detecção dos elementos contidos na pasta cerâmica, os fragmentos foram irradiados no centro da secção lateral, enquanto algumas áreas com decoração plástica remanescente também foram escolhidas e irradiadas nos lados convexo e côncavo de cada fragmento. Foram obtidas as composições dos pigmentos remanescentes em cada área analisada, subtraindo-se do espectro XRF da área considerada o espectro XRF da pasta cerâmica. Um programa baseado no método de representação poligonal gráfica foi desenvolvido e usado para correlacionar a intensidade representativa de cada fragmento.

UNITERMOS: Fragmentos cerâmicos - Tupi-Guarani-Composição de pigmentos arqueológicos - Composição de pasta-Fluorescência de raios X.

(*) Department of Chemical Engineer, State University of West Paraná, PR, Brazil.

(**) Physics Department, State University of Londrina (UEL), Londrina, PR, Brazil.

(***) Physics and Meteorology Department, ESALQ and Center of Nuclear Energy in the Agriculture (CENA),

University of São Paulo, Piracicaba, SP, Brazil .

\section{Introduction}

The Indian Brazilian pottery has been currently investigated only by traditional archaeological techniques. With the aim of extending the study of characteristics of superficial layer of the indian Brazilian 
pottery, we have recently applied non-destructive method which is based on the X-ray fluorescence technique (Appoloni et al. 1996). X-ray fluorescence analysis plays an important role for the determination of the inorganic components. The energy-dispersive detection of the characteristic X-rays has been widely applied as a non-destructive surface analysis providing a fast and nearly complete determination of the most important elements present as main components or as traces useful in the characterization of a great variety of archaeological objects.

In order to get information about the pigment composition from the pottery plastic decoration, the compositional data obtained from the different areas of each pottery fragment and generated by XRF analysis were normalized to their background spectrum counts, respectively. Its utility is to provide a qualitative paste-subtracted compositional data associated to trace elements employed as pigment in the pottery plastic decoration.

For the comparison between archaeological samples that have similar characteristics, a good samples comparison method is necessary. In XRF analysis, a large number of characteristic X-ray peaks normally represent a sample, but accuracy is difficult to achieve when results from many samples are to be compared. The Methodology of Graphic Representation of Samples is good in order to compare many multicomponent samples (Figueroa \& Caro 1994).

\section{Investigated objects}

The first evidences of human settlement in Paraná State, south of Brazil, are from around 10000 years ago. In this region, about 1500 years ago, horticulturalists and ceramists populations appeared, represented by the Tupi-Guarani and Itararé groups. The Tupi-Guarani lived in the valley regions of the Paraná, Ivaí, Tibagi and Iguaçu rivers. The Tupi-Guarani sites are related to the Guarani indians ancestors. Tupi-Guarani populations lived in the region of the Santa Dalmacia farm at the end of the XVI century or at the beginning of the XVII century and they had contact with the colonizers, probably Spanish, due to the observed changes in the pottery production characteristics. The Santa Dalmacia farm archaeological site was accidentally discovered in 1990 and belongs to Cambé city municipality, north of Paraná Brazilian State.
The investigated objects were eleven indian Brazilian pottery fragments from Santa Dalmacia farm archaeological site. Each one of these fragments came from a different ceramic recipient and all of them belong to Tupi-Guarani tradition. Besides the compositional characterization of the plastic decoration and the ceramic paste, this work is also devoted to the comparison of the ceramic pastes composition between typical Tupi-Guarani pottery fragments and the fragments that present characteristics of contact with the European colonizers.

Figures $1 \mathrm{~A}$ and $\mathrm{B}$ present the two sides of the eleven samples studied. Table 1 presents the characterization of the sherds paste. This classification was done by Maria Sherlowisk, from the Arts Department of the State University of Londrina.

Each one of Tupi-Guarani fragments shows very similar physical characteristics, except a ceramic recipient fragment (sample 11), so-called "of contact", which presents a style change within the local pottery production, exhibiting clearly a small cylindrical spout of European influence. A remaining pigment characterizes the convex surface of each fragment and several different superficial areas were chosen. The materials employed look very similar in texture and color. EDXRF spectra from several different surface areas of each pottery fragment were obtained.

\section{Experimental arrangement}

At the Radioisotopes Methodology Section, Center of Nuclear Energy in the Agriculture of the São Paulo University, Piracicaba, SP, Brazil, the energy dispersive $\mathrm{X}$-ray fluorescence measurements of the pottery fragments were performed using a conventional XRF spectrometer.

\subsection{EDXRF measurements}

The samples irradiated with radioisotope sources were placed on the top of an acrylic cylinder approximately $10 \mathrm{~cm}$ above the coaxial system source-detector. The goal of this work was the compositional characterization at Z-low and high elements within the pottery plastic decoration. The measurements were carried out at open air using radioactive sources and a X-ray tube. The following annular radioisotope sources were employed: ${ }^{238} \mathrm{Pu}$ (13 and $17 \mathrm{keV} ; 13 \% ; 95.2 \mathrm{mCi}$; 
ESPINOZA QUIÑNONE, F.R.; APPOLONI, C.R.; DOS SANTOS, A.O.; DASILVA, L.M.; BARBIERI, P.F.; ARAGÃO, P.H.; DO NASCIMENTO FILHO, V.F.; COIMBRA, M.M. EDXRF study of Tupi-Guarani archaeological ceramics. Rev. do Museu de Arqueologia e Etnologia, São Paulo, 13: 199-210, 2003.

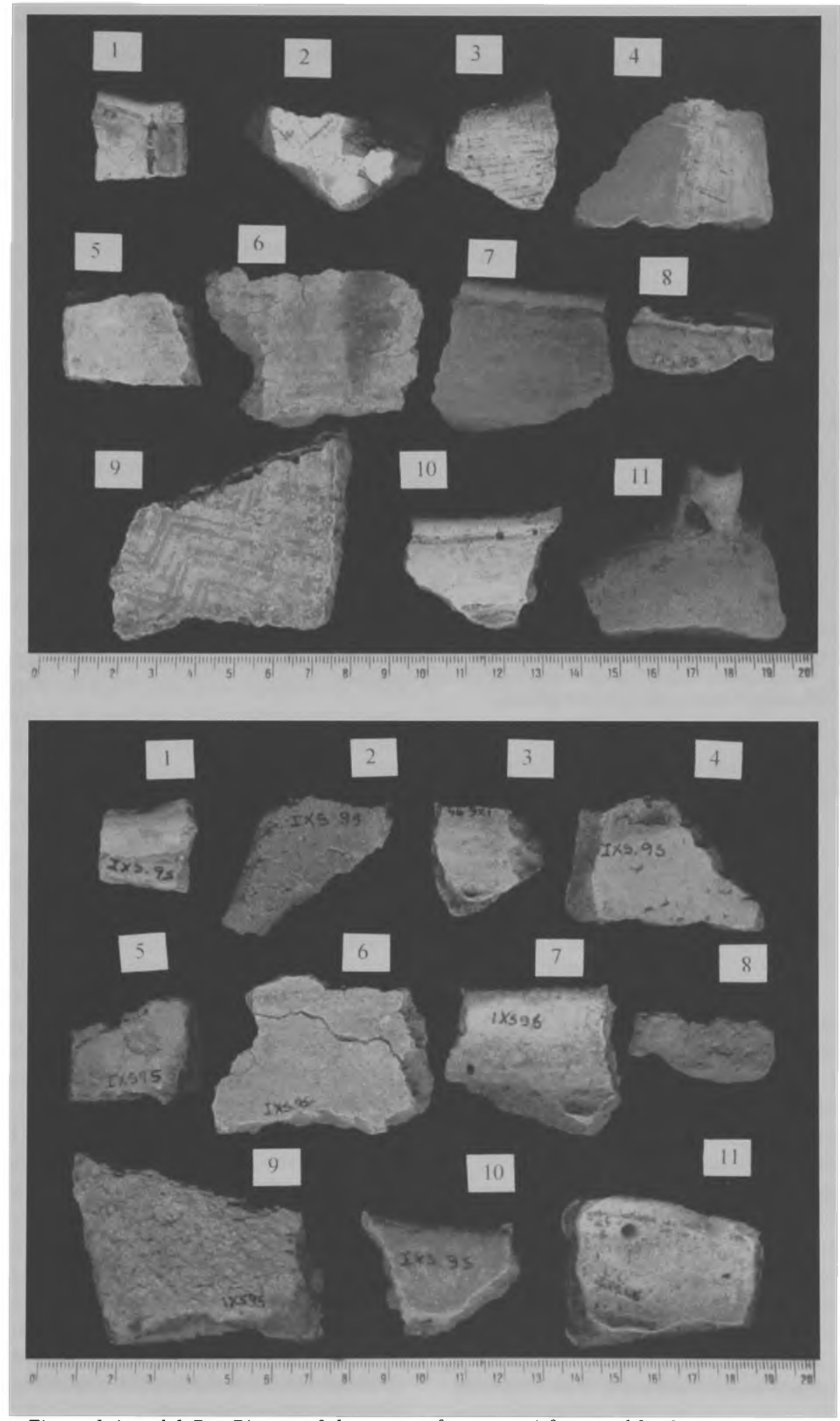

Figure $1 \mathrm{~A}$ and $I \mathrm{~B}$ - Picture of the pottery fragments (front and back view). 
TABLE 1

Characterization of the pottery fragments paste

\begin{tabular}{ll}
\hline Sherd & Paste Characterization \\
Label
\end{tabular}

$1 \quad$ Homogeneous paste with fine grains; almost complete firing; temper nor visible

2 Incomplete firing; caulin grains $(>5 \mathrm{~mm})$ and dark grains of non oxided ferrous minerals

3 Homogeneous paste with fine grains; caulin grains $(<5 \mathrm{~mm})$; weak firing

4 Homogeneous paste with fine grains; incomplete firing; temper nor visible

$5 \quad$ Round shape clear gray grains $(<2 \mathrm{~mm})$ of non oxided ferrous minerals; weak firing

6 Homogeneous paste with fine grains; temper nor visible; weak firing

7 Clear gray grains $(<2 \mathrm{~mm})$ of non oxided ferrous materials; weak firing

8 Homogeneous paste with fine grains; caulin grains $(<5 \mathrm{~mm})$; weak firing

9 Round shape clear gray grains $(<2 \mathrm{~mm})$ of non oxided ferrous minerals; weak firing

10 Homogeneous paste with fine grains; almost complete firing; temper nor visible

11 Clear gray grains $(<2 \mathrm{~mm})$ of non oxided ferrous materials; weak firing

$86 \mathrm{y}),{ }^{55} \mathrm{Fe}(6 \mathrm{keV} ; 28.5 \% ; 16.5 \mathrm{mCi} ; 2.6 \mathrm{y})$ and ${ }^{109} \mathrm{Cd}(22 \mathrm{keV} ; 107 \% ; 0.3 \mathrm{mCi} ; 1.2 \mathrm{y})$, .The X-ray tube was a conventional spectroscopic one, with molybdenum target and a zirconium filter, at an excitation energy of $15 \mathrm{kV}$ and $40 \mathrm{~mA}$. X-rays have been detected using a $\mathrm{Si}(\mathrm{Li})$ detector of 30 $\mathrm{mm}^{2}$, with a Be window, together to a multichannel analyzer. Using ${ }^{238} \mathrm{Pu}$ and ${ }^{55} \mathrm{Fe}$ excitation sources, the acquisition time for each measurement was preset at 40 minutes, while with a ${ }^{109} \mathrm{Cd}$ source it was preset at 2 hours due to have it a lower activity. With an X-ray tube, the time was fixed in 200 seconds. XRF spectra were stored on diskette and analyzed at the Physics Department, State University of Londrina, using a set of AXIL-QXAS programs elaborated and disseminated by the International Atomic Energy Agency in Vienna.

\section{Results and discussion}

\subsection{Elemental determination by EDXRF}

The characteristic $\mathrm{X}$-rays of elements were excited by means of three radioisotope sources and an X-ray tube. XRF spectra of each area show the similarity in the main elements of these fragments. Sixteen elements were identified by EDXRF within the measured fragments: $\mathrm{Al}, \mathrm{Si}, \mathrm{K}$, $\mathrm{Ca}, \mathrm{Ti}, \mathrm{Mn}, \mathrm{Fe}, \mathrm{Co}, \mathrm{Ni}, \mathrm{Cu}, \mathrm{Zn}, \mathrm{Ga}, \mathrm{Rb}, \mathrm{Sr}, \mathrm{Y}$ and $\mathrm{Zr}$. Furthermore, the elastic and inelastic scattering of incident radiation in the sample was considered as a part of the total background spectrum. The total background counts between the distinct samples appear rather different due to the sample parameter such as thickness and beamsample-detector geometry are not constant over the exposed sample volume.

For the determination of high elements, ${ }^{109} \mathrm{Cd}$ and ${ }^{238} \mathrm{Pu}$ sources were used. With the ${ }^{238} \mathrm{Pu}$ source, the overlap of $\mathrm{X}$-ray lines of $\mathrm{Z}$-high as $\mathrm{Rb}, \mathrm{Sr}, \mathrm{Y}$ and $\mathrm{Zr}$ elements and the elastic and inelastic scattering of Uranium L-X-rays is unavoidable. However, using the ${ }^{109} \mathrm{Cd}$ source, the compositional data for each of the parts of each individual fragment presents clearly high concentrations of $\mathrm{Zr}$ and Fe elements, while the Ti element is an order of magnitude lower. In addition, small amounts of $\mathrm{Cu}, \mathrm{Zn}, \mathrm{Rb}, \mathrm{Sr}$, and $\mathrm{Y}$ were detected in all the spectra indicating that their concentrations within the pottery fragments could be considerated at level of traces. Similarly, with the ${ }^{238} \mathrm{Pu}$ excitation source, all $\mathrm{X}$-ray spectra confirmed the presence of $\mathrm{Fe}$ at high concentration and an order of magnitude stronger than $\mathrm{Ti}$ element, while relatively small amounts of $\mathrm{K}, \mathrm{Ca}$, $\mathrm{Mn}, \mathrm{Ni}, \mathrm{Cu}$ and $\mathrm{Zn}$ elements were also detected.

On the other hand, the ${ }^{55} \mathrm{Fe}$ source was used for the determination of low atomic number elements. With this low-energy excitation source, elements as $\mathrm{Al}, \mathrm{Si}, \mathrm{K}$ and $\mathrm{Ca}$ were enhanced within the XRF spectra. The presence of these elements are an order of magnitude weaker than the amount of $\mathrm{Ti}$, indicating that $\mathrm{Al}, \mathrm{Si}, \mathrm{K}$ and $\mathrm{Ca}$ elements are also present at low concentrations within the pottery fragments. 
ESPINOZA QUIÑONES, F.R.; APPOLONI, C.R.; DOS SANTOS, A.O.; DA SILVA, L.M.; BARBIERI, P.F.; ARAGÃO, P.H.; DO NASCIMENTO FILHO, V.F.; COIMBRA, M.M. EDXRF study of Tupi-Guarani archaeological ceramics. Rev. do Museu de Arqueologia e Etnologia, São Paulo, 13: 199-210, 2003.

\subsection{Ceramic paste composition}

For the first eight ceramic pastes analyzed only with a ${ }^{238} \mathrm{Pu}$ source, the compositional data related to the sum of all characteristic $\mathrm{X}$-rays intensities in the sample are presented in Table 2. Similarly, the data for more others three ceramic pastes analyzed with ${ }^{238} \mathrm{Pu},{ }^{109} \mathrm{Cd}$ and ${ }^{55} \mathrm{Fe}$ and an $\mathrm{X}$-ray tube are summarized in Tables 3, 4 and 5. The later, labeled as paste 11 , corresponds to the sample so-called of contact.
4.3 Pigment composition of the plastic decoration

Indeed the strong elemental contribution within the samples came mainly out the ceramic paste. In order to achieve a more accurate assessment from the pigment composition in all areas analyzed of each fragment, the elemental intensities data were normalized to their total background spectrum counts, respectively, and subtracted statically from their corresponding

TABLE 2

Intensity of each element within the eight ceramic pastes, labeled as paste from 1 to 8 , related to the sum of all characteristic $X$-rays intensities using only a ${ }^{238}$ Pu source

\begin{tabular}{|c|c|c|c|c|c|c|c|c|}
\hline & $\begin{array}{c}\text { Paste } 01 \\
{ }^{238} \mathbf{P u}\end{array}$ & $\begin{array}{c}\text { Paste } 02 \\
{ }^{238} \mathrm{Pu}\end{array}$ & $\begin{array}{c}\text { Paste 03 } \\
{ }^{238} \mathbf{P u}\end{array}$ & $\begin{array}{c}\text { Paste } 04 \\
{ }^{238} \mathrm{Pu}\end{array}$ & $\begin{array}{c}\text { Paste } 05 \\
{ }^{238} \mathbf{P u}\end{array}$ & $\begin{array}{c}\text { Paste } 06 \\
{ }^{238} \mathrm{Pu}\end{array}$ & $\begin{array}{c}\text { Paste } 07 \\
{ }^{238} \mathbf{P u}\end{array}$ & $\begin{array}{c}\text { Paste } 08 \\
{ }^{238} \mathbf{P u}\end{array}$ \\
\hline $\mathbf{K}$ & $0.19 \quad(9)$ & & & & 0 & & $(5)$ & 4 \\
\hline $\mathbf{C a}$ & 1 & & & & (10) & 09 (4) & 0.29 (6) & 9 \\
\hline $\mathbf{T i}$ & & & & & & 3 & (10) & 4 \\
\hline Mn & & & & & & $3(5)$ & & 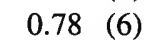 \\
\hline $\mathbf{F e}$ & & & & & & $3(31)$ & & 92. \\
\hline & (14) & & & & $0.88(14)$ & (1 & $0.90(11)$ & $0.61(1$ \\
\hline $\mathbf{N i}$ & & & & & & 12 & & \\
\hline $\mathrm{C}_{3}$ & 1.25 & & & & ) & 64 & 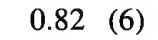 & 3 \\
\hline & 0 . & & & & ( & 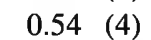 & 8 & 8 \\
\hline d & $0.22 \quad(7)$ & & 7) & 0.19 (9) & $0.26 \quad(6)$ & $0.07 \quad 3$ & 0.13 & 0.13 \\
\hline
\end{tabular}

\section{TABLE 3}

Intensity of each element within the ceramic paste, labeled as paste 9 , related to the sum of all characteristic $\mathbf{X}$-rays intensities for each excitation source

\begin{tabular}{|c|c|c|c|}
\hline & ${ }^{55} \mathrm{Fe}$ & X-ray Tube & ${ }^{238} \mathbf{P u}$ \\
\hline $\mathbf{A l}$ & $3.09(15)$ & & \\
\hline $\mathbf{S i}$ & $6.90(21)$ & & \\
\hline $\mathbf{K}$ & $2.52(13)$ & $0.10 \quad(2)$ & \\
\hline $\mathbf{C a}$ & $10.51(27)$ & $0.41 \quad(3)$ & 0.27 \\
\hline $\mathbf{T i}$ & $76.98(68)$ & $5.09 \quad(6)$ & $4.34 \quad(9)$ \\
\hline Mn & & $0.30 \quad(2)$ & $0.48 \quad(5)$ \\
\hline $\mathbf{F e}$ & & $92.30(24)$ & $93.00(34)$ \\
\hline Co & & $0.77 \quad(6)$ & $0.98(10)$ \\
\hline \multicolumn{4}{|l|}{$\mathbf{N i}$} \\
\hline $\mathbf{C u}$ & & $0.51 \quad$ (3) & 0.56 \\
\hline $\mathbf{Z n}$ & & $0.38 \quad(3)$ & $0.36 \quad(4)$ \\
\hline $\mathbf{G a}$ & & $0.15 \quad(2)$ & \\
\hline
\end{tabular}

\section{TABLE 4}

Intensity of each element within the ceramic paste, labeled as paste 10, related to the sum of all characteristic $X$-rays intensities for each excitation source

\begin{tabular}{lrrrrrr}
\hline & ${ }^{55} \mathbf{F e}$ & X-ray Tube & ${ }^{238} \mathbf{P u}$ & ${ }^{109} \mathbf{C d}$ \\
\hline \hline $\mathbf{A l}$ & $2.07(7)$ & & & & & \\
$\mathbf{S i}$ & $4.87(11)$ & & & & & \\
$\mathbf{K}$ & $2.62(9)$ & & & 0.12 & $(5)$ & \\
$\mathbf{C a}$ & $4.47(11)$ & 0.09 & $(2)$ & 0.26 & $(5)$ & \\
Ti & $85.96(42)$ & 7.54 & $(5)$ & $7.51(11)$ & $5.59(35)$ \\
$\mathbf{M n}$ & & 0.78 & $(2)$ & 0.63 & $(5)$ & \\
Fe & & $87.86(90)$ & $89.37(33)$ & $72.60(83)$ \\
$\mathbf{C o}$ & & $2.27(6)$ & $0.84(10)$ & \\
Ni & & 0.15 & $(2)$ & & & \\
$\mathbf{C u}$ & & 0.67 & $(2)$ & 0.66 & $(4)$ & \\
$\mathbf{Z n}$ & & 0.43 & $(2)$ & 0.47 & $(4)$ & \\
$\mathbf{G a}$ & & 0.21 & $(2)$ & 0.14 & $(3)$ & \\
$\mathbf{S r}$ & & & & & & $1.35(26)$ \\
$\mathbf{Y}$ & & & & & & $1.14(25)$ \\
$\mathbf{Z r}$ & & & & & & $19.32(52)$ \\
\hline
\end{tabular}




\section{TABLE 5}

Intensity of each element within the ceramic paste of contact, labeled as paste 11, related to the sum of all characteristic $X$-rays intensities for each excitation source

\begin{tabular}{lrrrr}
\hline & ${ }^{55} \mathbf{F e}$ & X-ray Tube & \multicolumn{1}{c}{${ }^{238} \mathbf{P u}$} \\
\hline \hline $\mathbf{A l}$ & $2.14(9)$ & & & \\
$\mathbf{S i}$ & $5.58(14)$ & & & \\
$\mathbf{K}$ & $3.66(11)$ & $0.10(2)$ & $0.30(5)$ \\
$\mathbf{C a}$ & $4.21(13)$ & $0.41(3)$ & $0.30(5)$ \\
$\mathbf{T i}$ & $84.42(50)$ & $5.09(6)$ & $8.88(12)$ \\
$\mathbf{M n}$ & & $0.30(2)$ & $0.44(5)$ \\
$\mathbf{F e}$ & & $92.30(24)$ & $87.69(35)$ \\
$\mathbf{C o}$ & & $0.77(6)$ & $0.79(10)$ \\
$\mathbf{N i}$ & & & & \\
$\mathbf{C u}$ & & $0.51(3)$ & $0.85(6)$ \\
$\mathbf{Z n}$ & & $0.38(3)$ & $0.55(5)$ \\
$\mathbf{G a}$ & & $0.15(2)$ & $0.20(4)$ \\
\hline
\end{tabular}

normalized paste composition, as shown in Tables 6 and 7

The presence of a very high Iron concentration characterizes all samples, but some of them with red coloration in the plastic decoration show an increase in the intensity of the Iron peak compared to the paste. The red coloration could be attributed to Iron Oxide in the form of Hematite which, at the Paraná state, appears as a component of Laterite (Appoloni et al. 1996).

In the pottery plastic decoration, the dark coloration is used on the design motifs in the slip. In Figure 2, the spectrum for the dark coloration of the slip shows an increase of the Manganese peak an order of magnitude with respect to the paste. The paste-subtracted compositional data

\section{TABLE 6}

The paste-subtracted compositional data normalized to the sum of characteristic $\mathbf{X}$-rays intensities for some areas on the pottery plastic decoration analyzed with a ${ }^{238} \mathrm{Pu}$ source

\begin{tabular}{|c|c|c|c|c|c|c|}
\hline & $\begin{array}{l}\text { Paste } 01 \\
{ }^{238} \mathrm{Pu}\end{array}$ & $\begin{array}{c}\text { Paste 03 } \\
{ }_{\text {238Pu }} \mathbf{P u}\end{array}$ & $\underset{\text { Paste } 04}{{ }^{238} \mathrm{Pu}}$ & $\begin{array}{c}\text { Paste } 05 \\
{ }^{238} \mathbf{P u}\end{array}$ & $\begin{array}{c}\text { Paste 06a } \\
{ }^{238} \mathrm{Pu}\end{array}$ & $\begin{array}{c}\text { Paste 06b } \\
{ }^{238} \mathrm{Pu}\end{array}$ \\
\hline $\mathbf{K}$ & & & $46(21)$ & $39(6)$ & & $49(22)$ \\
\hline $\begin{array}{l}\mathrm{Ca} \\
\mathrm{Ti}\end{array}$ & & $25.0(43)$ & & & $20(10)$ & \\
\hline $\begin{array}{r}\mathbf{T i} \\
\mathbf{M n}\end{array}$ & $75.4(18)$ & & $14(2)$ & & $16(1)$ & \\
\hline $\mathbf{F e}$ & $15.4(27)$ & & & $4(1)$ & & \\
\hline Ni & $2.2(6)$ & $74.3(39)$ & $14(3)$ & $34(7)$ & & $11(5)$ \\
\hline $\mathrm{Cu}$ & $3.0(3)$ & & & & $12(1)$ & $20(2)$ \\
\hline $\mathbf{Z n}$ & $4.1(7)$ & $0.7(4)$ & $26(4)$ & $5(1)$ & 33 (3) & $3(1)$ \\
\hline Ga & & & & $18(5)$ & $19(8)$ & $18(8)$ \\
\hline
\end{tabular}

TABLE 7

The ceramic paste compositional data normalized to the sum of characteristic $\mathrm{X}$-rays intensities for the samples 9,10 and 11

\begin{tabular}{|c|c|c|c|c|c|c|c|}
\hline & $\underset{{ }^{5} \mathbf{P u}}{\text { Paste } 09}$ & $\underset{{ }^{55} \mathrm{Pu}}{\text { Paste } 10}$ & $\underset{{ }^{55} \mathbf{P u}}{\text { Paste } 11}$ & $\begin{array}{c}\text { Paste } 09 \\
{ }^{238} \mathbf{P u}\end{array}$ & $\begin{array}{l}\text { Paste } 10 \\
{ }^{238} \mathbf{P u}\end{array}$ & $\underset{{ }^{238} \mathbf{P u}}{\text { Paste } 11}$ & $\underset{{ }^{238} \mathbf{P u}}{\text { Paste 11a }}$ \\
\hline $\begin{array}{l}\mathbf{A l} \\
\mathbf{S i}\end{array}$ & $20(6)$ & $\begin{array}{r}2(1) \\
26(2)\end{array}$ & & & & & \\
\hline $\mathbf{K}$ & & $72(2)$ & & & $6(1)$ & & \\
\hline $\mathrm{Ca}$ & & & $100(21)$ & $13(5)$ & & & \\
\hline Ti & $80(7)$ & & & 71 (11) & $4(1)$ & $2(1)$ & \\
\hline Mn & & & & & & $5(1)$ & $41(12)$ \\
\hline $\mathbf{F e}$ & & & & & $77(2)$ & $90(2)$ & \\
\hline Co & & & & & & $2(1)$ & \\
\hline $\mathbf{N i}$ & & & & & & & \\
\hline $\mathbf{C u}$ & & & & $12(5)$ & $6(1)$ & & $25(12)$ \\
\hline $\mathbf{Z n}$ & & & & & $5(1)$ & & 34 (11) \\
\hline Ga & & & & & $2(1)$ & & \\
\hline
\end{tabular}


for the dark pigment is shown in Table 6, labeled as sample 01 .

The dark brown pigment is observed on the sample so-called of contact at the spout external side. This pigment produces a significant increase in the Manganese content compared to the paste, as shown in Figure 3. The paste-subtracted compositional data for the dark brown pigment is shown in Table 7 and labeled as sample 11a. Manganese is only present in the dark pigment in a substantial amount. The ceramic paste and others remaining pigments only show very low amounts of Manganese.
The white coloration in the pottery plastic decoration is mainly due to the presence of Potassium, which exhibits clearly an increase in its intensity in comparison with the paste, as shown in Figure 4. The paste-subtracted compositional data for the white pigment is shown in Table 7 where the sample is labeled as 10 and analyzed using a ${ }^{55} \mathrm{Fe}$ source.

\subsection{Method of graphic representation}

The results of compositional data of each fragment were compared using the method of

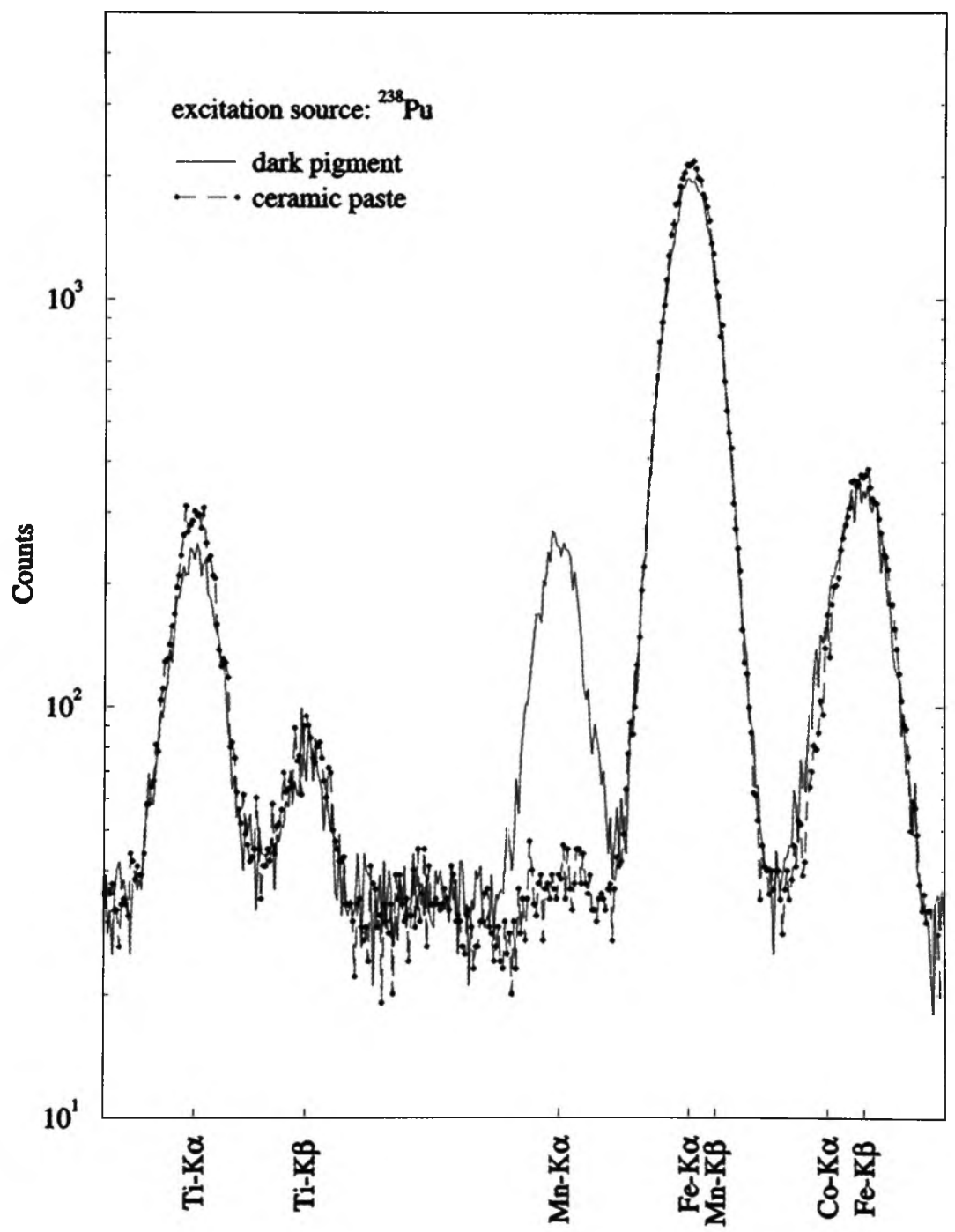

Figure $2-X R F$ spectra for the dark pigment and the ceramicpaste. 


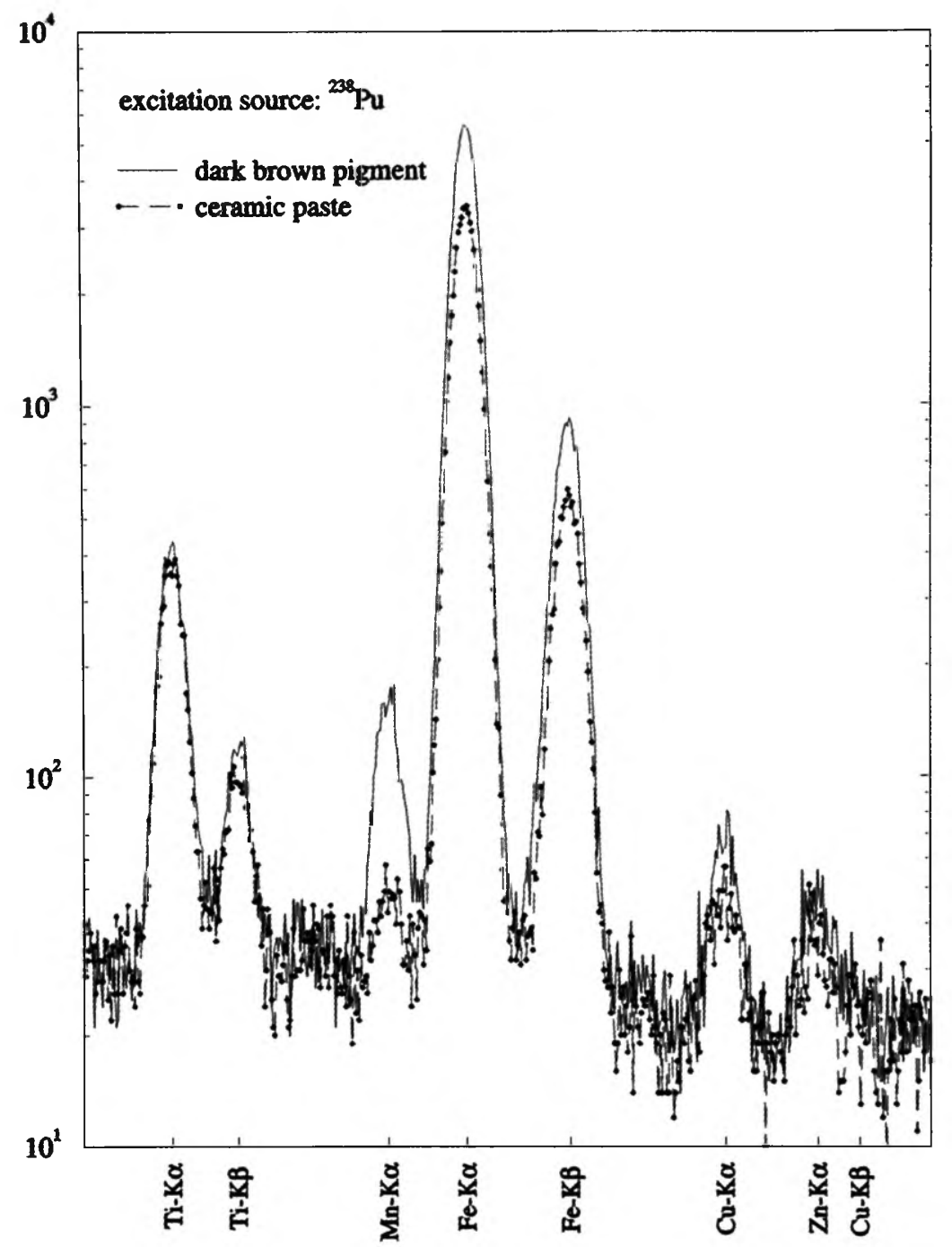

Figure 3 - XRF spectra for the dark brown pigment and the ceramic paste.

graphic representation. This method reduces a multicomponent sample as a single vector, whose magnitude is drawn in two dimensions inside a regular polygon of axes equal to one in order to improve visualization. The vector sample is defined in terms of non-perpendicular vector component which can be the X-ray intensity of each element related to the sum of all representative $\mathrm{X}$-rays intensities in the sample (Figueroa \& Caro 1994). Each axes of non-perpendicular components are drawn every $2 p / n$ angle of separation, where $n$ is the number of representative elements. A regular polygon of a higher order is more representative of the sample. The X-ray intensities calculated with AXIL were used as input to construct polygons of representation with software developed at the Physics Department, State University of Londrina.

Using a ${ }^{238} \mathrm{Pu}$ source, the Iron and Titanium concentrations within the sample are by far the major. When these major elements are left out, the representative points of eleven ceramic pastes inside of the regular octagon fall around the 


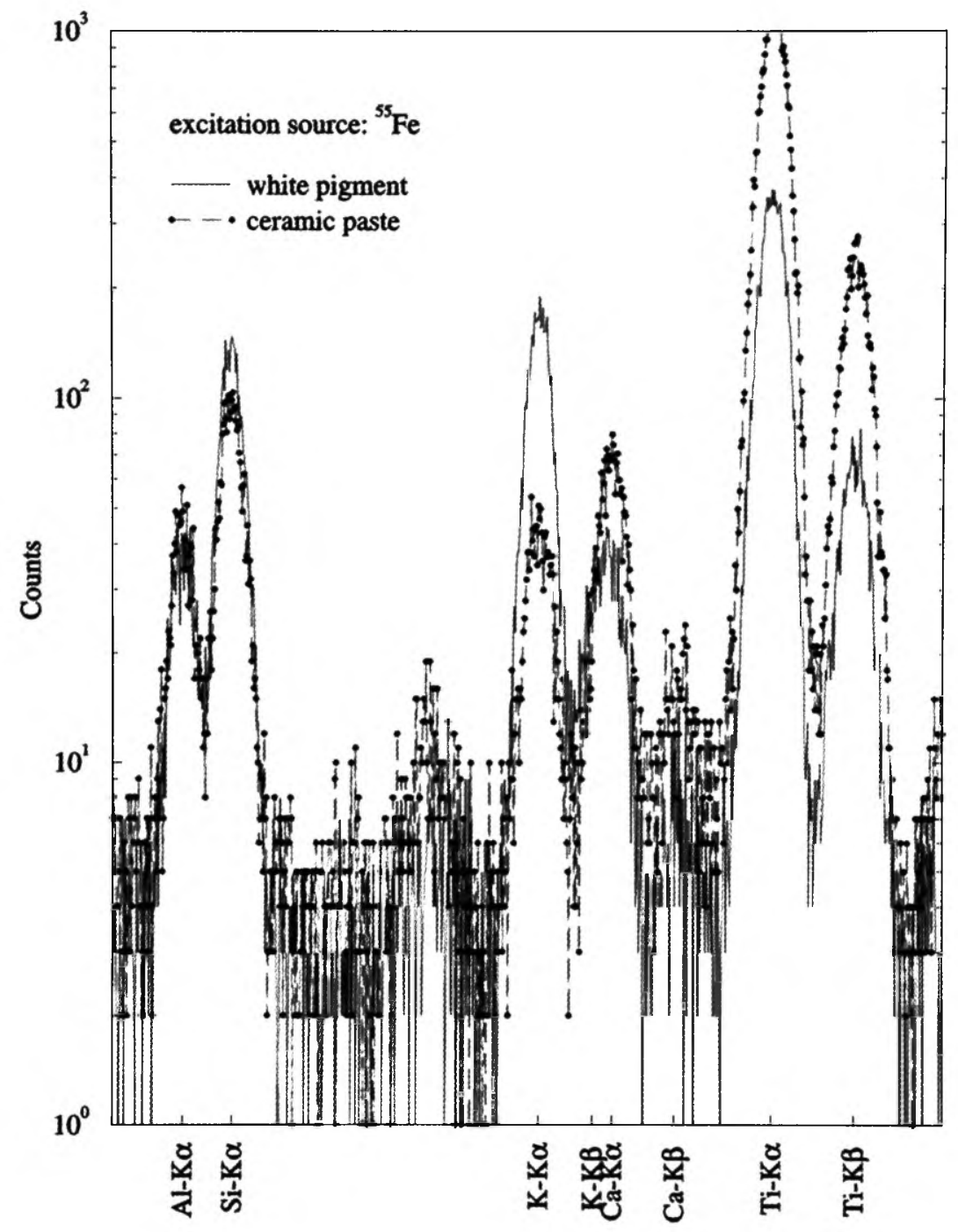

Figure $4-X R F$ spectra for the white pigment and the ceramic paste.

same region as shown in Figure 5. Similarly, a high degree of correlation between the all samples is also obtained when Iron and Titanium elements are added, showing that the materials employed in the pottery production are the same origin. In Figure 6, on the other hand, when the plastic decoration compositions are compared, the representative points of some superficial areas in the sample such as the dark pigment (labeled as sample 01) and the dark brown pigment (labeled as sample 11a) change their relative positions, indicating that the pigments employed in the plastic decoration are from different origin. When a diagram of a lower order is considered, each representative point is positioned next to the element of high concentration such as Manganese element in dark pigment (sample 01).

This methodology was also applied to the results of ceramic paste and plastic decoration compositions obtained with a ${ }^{55} \mathrm{Fe}$ source. Pentagonal representations of three samples are 


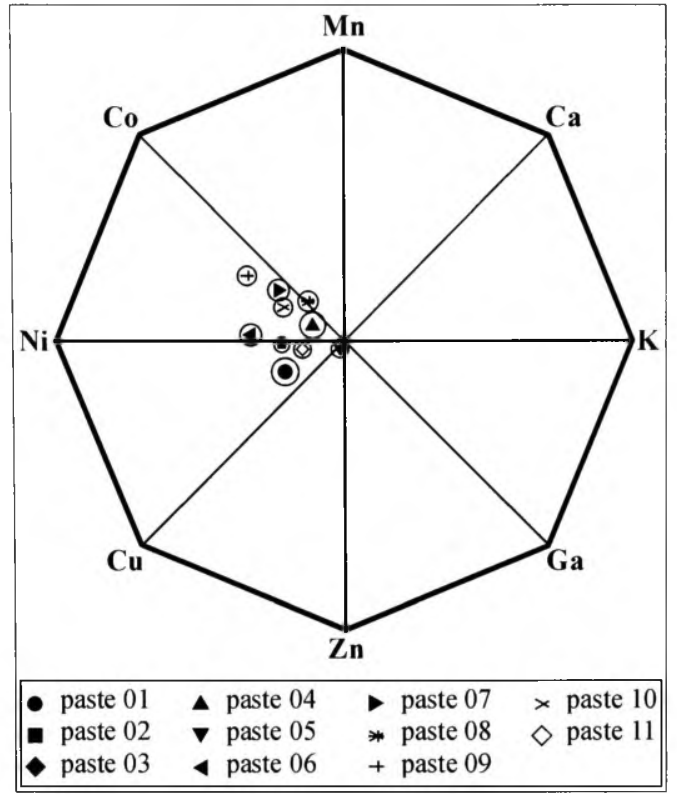

Figure 5 - Graphic representation of ceramic pastes analyzed with a ${ }^{238} \mathrm{Pu}$ source.

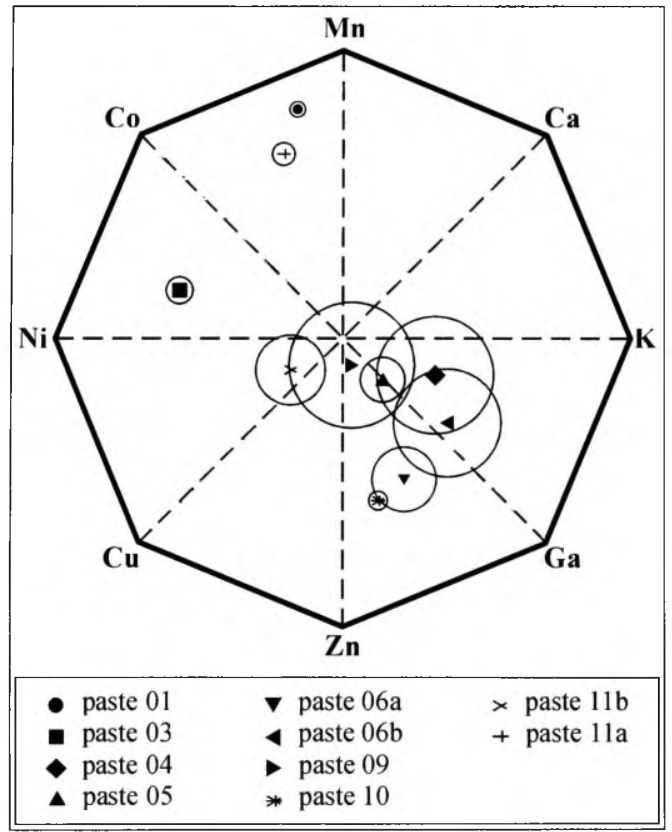

Figure 6 - Graphic representation of pottery decoration analyzed with a ${ }^{238} \mathrm{Pu}$ source. present in Figures 7 and 8. For the ceramic past labeled as paste from 9 to 11 , the representative points have nearby locations and all of them are next to Titanium element, as shown in Figure 7. These samples show a great similarity, indicating the same origin. On the other hand, the representative points corresponding to the plastic decoration are clearly separated, as shown in Figure 8 . The sample 09 is located in the diagram between Potassium and Silicon elements, which characterize the white pigment.

\section{Conclusions}

Sixteen elements were identified by EDXRF within the pottery fragments from Santa Dalmacia farm archaeological site. A systematic presence of relatively high concentrations of $\mathrm{Ti}, \mathrm{Fe}$ and $\mathrm{Zr}$ can characterize the ceramic pastes. Furthermore, the concentrations of $\mathrm{Al}, \mathrm{Si}, \mathrm{K}, \mathrm{Ca}, \mathrm{Mn}, \mathrm{Co}, \mathrm{Ni}, \mathrm{Cu}$ and $\mathrm{Zn}$ could be considerated at level of traces within the ceramic pastes. Small amounts of $\mathrm{Rb}, \mathrm{Sr}$, and $\mathrm{Y}$ are also present. The black pigment in the pottery plastic decoration is mainly due to the

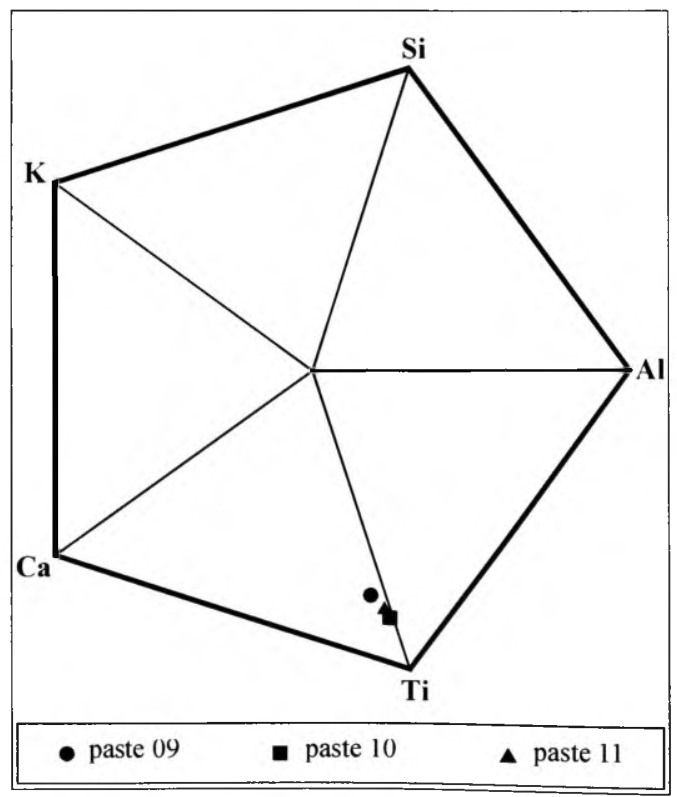

Figure 7 - Graphic representation of ceramic pastes analyzed with a ${ }^{55} \mathrm{Fe}$ source. 


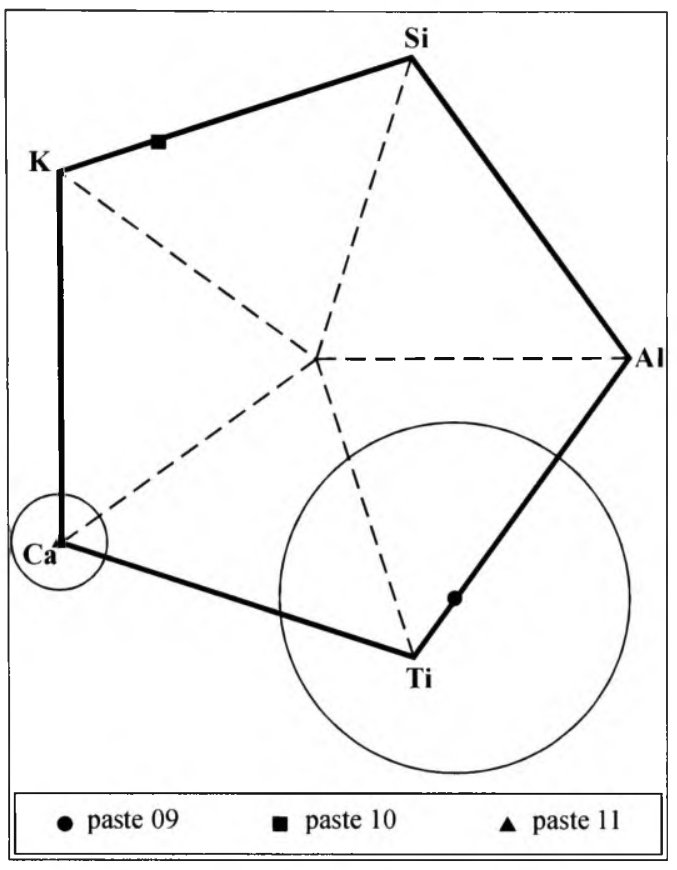

Figure 8-Graphic representation of pottery plastic decoration analyzed with $a{ }^{55} \mathrm{Fe}$ source. presence of Manganese. The red pigment is produced by the presence of Iron, while the white pigment is characterized by the presence of Potassium. For the eleven fragments, the graphic representation point to same materials employed in the pottery production. In addition, the pigments in the plastic decoration were obtained from different inorganic materials.

\section{Acknowledgements}

The authors would like to thank: Historical Museum of Cambé, Paraná, Brazil, for the provision of the pottery fragments used in this investigation; Paulo Parreira and Fabio Lopes for helping with some aspects of the data acquisition; Profs. Maria Sherlowisk, Ubirajara Senatori and Udhi Jozzolino, from the Arts Department, for the classification of the ceramic fragments; archaeologist Claudia Inês Parellada, from the "Museu Paranaense", for helping with the paste characterization of the sherds; National Science Council (CNPq) and Cultural Incentive Law of Londrina, for the support of this work.

ESPINOZAQUIÑNONES, F.R.; APPOLONI, C.R.; DOS SANTOS, A.O.; DA SILVA, L.M.; BARBIERI, P.F.; ARAGÃO, P.H.; DO NASCIMENTO FILHO, V.F.; COIMBRA, M.M.EDXRF study of Tupi-Guarani archaeological ceramics. Rev. do Museu de Arqueologia e Etnologia, São Paulo, 13: 199-210, 2003.

ABSTRACT: A set of indian Brazilian pottery fragments belonging to Tupi-Guarani tradition has been studied by an archaeometric non-destructive technique. The pottery fragments were accidentally discovered in the Santa Dalmacia farm, sited near Cambé city at the north of Paraná Brazilian state. Each one of these fragments came from different ceramic recipients and their physical characteristics are very similar. The EDXRF measurements were performed employing both an X-ray tube and three radioisotope sources $(\mathrm{Fe}, \mathrm{Cd}$ and $\mathrm{Pu})$. The compositional data of the ceramics paste and pigments is investigated. For detection of the elements within the ceramic paste, the fragments were irradiated at the center of the lateral section, while several superficial areas with remaining plastic decoration were also chosen and irradiated at the convex and concave sides of each fragment. A paste-subtracted compositional data of the remaining pigments was statically extracted from the XRF analysis of each area. A program based on the graphic polygonal representation method was developed and used to correlate the representative intensity data of each fragment.

UNITERMS: Ceramic sherds - Tupi-Guarani, archaeological, pigment composition, paste composition, $\mathrm{X}$-ray fluorescence. 
ESPINOZA QUIÑONES, F.R.; APPOLONI, C.R.; DOS SANTOS, A.O.; DA SILVA, L.M.; BARBIERI, P.F.; ARAGÃO, PH.; DO NASCIMENTO FILHO, V.F.; COIMBRA, M.M. EDXRF study of Tupi-Guarani archaeological ceramics. Rev. do Museu de Arqueologia e Etnologia, São Paulo, 13: 199-210, 2003.

\section{References}

APPOLONI, C.R.; PARREIRA, P.S.; SOUZA, E.; QUACCHIA, J.C.A.; NASCIMENTO FILHO, V.F. DO; GIGANTE, G.E.; CESAREO, R.; CUNHAE SILVA, R.M.

1996 Non-Destructive Analysis of Brazilian archaeological Pottery from the region of Londrina city, Proceedings of $5^{\text {th }}$ International Conference on Non-Destructive Testing, Microanalytical Methods and
Environmental Evaluation for Study and Conservation of Works of arts. Hungary, Budapest: 76-81.

FIGUEROA, R.G;CARO, D.G

1994 A new Method of Graphic Representation of Sample Analyzed by XRF. J.V. Gilfrich $e t$ al.(Eds.) Advances in X-Ray Analysis, 37. New York, Plenum Press: 741-747.

Recebido para publicação em 30 de julho de 2003. 